DedikasiMU (Journal of Community Service)

Volume 3, Nomor 3, September 2021

\title{
PELATIHAN PERSONAL BRANDING DAN PRODUCT BRANDING \\ PADA KARANG TARUNA DALAM MENINGKATKAN PEMASARAN SERTA \\ PENJUALAN PRODUK UMKM DESA KLANGONAN GRESIK GRESIK
}

\author{
Wenti Krisnawati $^{1}$ \\ ${ }^{1}$ Dosen Program Studi Manajemen, Universitas Muhammadiyah Gresik \\ Email: lppm@umg.ac.id
}

\begin{abstract}
ABSTRAK
Sebelum kita membahas terkait dengan bagaimana kita memasarkan produk hasil UMKM desa klangonan, adalah persiapan dari pemilik usaha yaitu terkait personal branding. Menurut Haroen (2014), personal branding adalah proses membentuk persepsi masyarakat terhadap aspek-aspek yang dimiliki seseorang, seperti kepribadian, kemampuan, atau nilainilai dan bagaimana semua itu menciptakan persepsi positif dari masyarakat yang dapat digunakan sebagai alat pemasaran. Permasalahan yang sering terjadi Ketika memasarkan sebuah produk adalah kemampuan berbicara didepan umum, karena kemampuan berbicara didepan umum adalah hal yang akan mempengaruhi seorang pelaku usaha untuk mempromosikan produk baik secara langsung dan tidak langsung. Begitupun dengan para karang taruna desa klangonan ini dimana mereka sudah mempunyai produk namun belum mampu mempromosikan produknya dengan baik.Hasil dari pelatihan mampu percaya diri untuk mempromosikan produk masing-masing. Peserta juga memiliki mini video terkait pembuatan iklan atas produknya.
\end{abstract}

Kata kunci : Etika Komunikasi, Personal Branding, Product Branding. 


\section{DedikasiMU (Journal of Community Service)}

Volume 3, Nomor 3, September 2021

\section{PENDAHULUAN}

\section{A. Latar Belakang}

Sebelum kita membahas terkait dengan bagaimana kita memasarkan produk hasil UMKM desa klangonan, adalah persiapan dari pemilik usaha yaitu terkait personal branding. Menurut Haroen (2014), personal branding adalah proses membentuk persepsi masyarakat terhadap aspek-aspek yang dimiliki seseorang, seperti kepribadian, kemampuan, atau nilai- nilai dan bagaimana semua itu menciptakan persepsi positif dari masyarakat yang dapat digunakan sebagai alat pemasaran.

Menurut Montoya (2002), dalam membentuk personal branding diperlukan elemen-elemen yang harus saling terintegrasi dan dibangun bersamaan, yaitu: You, atau dengankata lain, seseorang itu sendiri. Seseorang dapat membentuk sebuah personal branding melalui sebuah polesan dan metode komunikasi yang disusun dengan baik. Relationship.Sebuah personal branding yang baik akan mampu menciptakan suatu relasi yang baik dengan klien, semakin banyak atribut-atribut yang dapat diterima oleh klien dan semakintingginya tingkat kekuasaan seseorang, menunjukkan semakin baiknya tingkat relasi yangada pada personal branding tersebut.

Dengan melatih para karang taruna ini untuk mempersiapkan diri menyiapkan strategipemasarannya, terlebih dahulu kami melatih kemampuan mereka untuk berbicara didepanumum dengan percaya diri hingga ketika mereka mulai memasarkan produknya mereka telahsiap untuk semua itu.

Setelah kami melatih kemampuan berkomunikasi para peserta kami juga memberikanpelatihan yaitu terkait Product Branding. Menurut Kotler (2009) produk adalah entitas yang dipasarkan dapat berupa barang, jasa, acara, properti. orang, tempat, informasi, danide. Produk UMKM yang dijual di pasar dapat memiliki jenis dan branding dalam jumlahyang banyak sekali. Di dalam satu desa saja, kita dapat menemui puluhan hingga ratusanpenjual makanan dan minuman. Olehkarena itu, pebisnis UMKM harus mengelola secarabaik product branding yang akan dikenalkan pada masyarakat umum. 


\section{DedikasiMU (Journal of Community Service)}

Volume 3, Nomor 3, September 2021

Product branding merupakan usaha pemberian identitas pada sebuah produk yang mempu mempengaruhi konsumen untuk memilih dan membeli produk tersebut jika dibandingkan dengan produk pesaing lainnya yang ada di pasar. Sedangkan pengertian branding adalah nama, istilah, tanda, lambing atau desain, atau kombinasinya, yang dimaksudkan untuk mengidentifikasi barang atau jasa dari salah satu penjual atau kelompok penjual dan mendiferensiasikan mereka dari pesaing.

Pada product branding, pebisnis UMKM akan memahami bahwa branding adalah sesuatu yang penting. Branding dapat mempermudah dalam penelusuran produk, menandakan kualitas suatu produk, bahkan dapat menjadi perlindungan hukum apabila sudahterdaftar dalam Hak Cipta suatu produk.

\section{METODE PELAKSANAAN}

\section{A. Kerangka Pemecahan Masalah}

Menurut Montoya dan Vandehey (2008), dalam membentuk personal branding diperlukan elemen-elemen yang harus saling terintegrasi dan dibangun bersamaan, yaitu: You, atau dengan kata lain, seseorang itu sendiri. Seseorang dapat membentuk sebuah personal branding melalui sebuah polesan dan metode komunikasi yang disusu n dengan baik. Setelah kami melatih kemampuan berkomunikasi para peserta kami juga memberikanpelatihan yaitu terkait Product Branding. Menurut Kotler (2009) produk adalah entitas yangdipasarkan dapat berupa barang, jasa, acara, properti. orang, tempat, informasi, dan ide. Produk UMKM yang dijual di pasar dapat memiliki jenis dan branding dalam jumlah yangbanyak sekali. Di dalam satu desa saja, kita dapat menemui puluhan hingga ratusan penjualmakanan dan minuman. Olehkarena itu, pebisnis UMKM harus mengelola secara baik product branding yang akan dikenalkan pada masyarakat umum. 


\section{DedikasiMU (Journal of Community Service)}

Volume 3, Nomor 3, September 2021

Tabel 1. Tahapan Kegiatan

\begin{tabular}{|c|c|}
\hline TAHAPAN & URAIAN KEGIATAN \\
\hline Sosialisasi & $\begin{array}{l}\text { Tujuan dari sosialisasi ini adalah mendapatkan pemahaman } \\
\text { serta megidentifikasi bersama tentang tujuan, manfaat dan } \\
\text { capaian yang diharapkan dari kegiatan pelatihan Personal } \\
\text { Branding dan ProductBranding serta menyepakati langkah- } \\
\text { langkah dan bentuk kegiatan yang akan dilaksanakan secara } \\
\text { Bersama antara pihak universitas dan mitra }\end{array}$ \\
\hline $\begin{array}{l}\text { Pelatihan dan } \\
\text { Pengenalan Personal } \\
\text { Branding dan Product } \\
\text { Branding }\end{array}$ & $\begin{array}{l}\text { Dengan melatih para karang taruna ini untuk } \\
\text { mempersiapkan diri menyiapkan strategi pemasarannya, } \\
\text { terlbih dahulu kami melatih kemampuan mereka untuk } \\
\text { berbicara didepan umum dengan percaya diri hingga } \\
\text { Ketika mereka mulai memasarkan produknya mereka telah } \\
\text { siap untuk semua itu. }\end{array}$ \\
\hline Pelaksanaan & $\begin{array}{l}\text { Tujuan dari diadakan pelatihan komunikasi Personal } \\
\text { Branding dan Product Branding adalah salah satu upaya } \\
\text { Instansi universitas Muhammadiyah Gresik membimbing } \\
\text { para pelaku bisnis UMKM agar lebih bisa menggunakan } \\
\text { kompetensi komunikasi mereka dan tidakhanya membuat } \\
\text { produk saja. Lalu diharapkan pula mitra benar-benar } \\
\text { memahami terkait merek produk yang akan dibawa selama } \\
\text { berbisnis nantinya. Dimana merek dengan pengelolaan yang } \\
\text { menarik adalah halyang sangat penting bagi sebuah produk }\end{array}$ \\
\hline
\end{tabular}




\section{DedikasiMU (Journal of Community Service)}

Volume 3, Nomor 3, September 2021

\section{B. Realisasi Pemecahan Masalah}

Kegiatan pelatihan Personal Branding dan Produk Branding. Kegiatan ini dilakukan duadosen dari prodi Manajemen. Kegiatan Personal Branding dan Produk Branding dilakukan oleh dosen secara kelompok dan dihadiri oleh perangkat desaa dan karang taruna sebagai peserta. Para peserta yakni karang taruna dating dengan membawa produk (bagi yang memilikiproduk) dan peserta sangan antusias terkait kegiatan ini. Sesuai dengan judul kegiatan bahwasannya disini dosen melakukan pengajaran serta pendampingan terkait dengan bagaiamana membentuk personal branding serta setelah mereka mampu membentuk personalbranding maka akan mudah bagi peserta untuk memasarkan produk dengan pelatihan brandingproduk yang mereka miliki. Peserta melakukan persiapan yang dimulai dari hal berikut :

1. Persiapan materi dan fisik, hal pokok dalam mempersiapakan presentasi (bahan tayang, busana, dan juga alat bantu sperti pointer). Karena persiapan diri dalam berpresentasi akanmenjadikan branding tersendiri bagi setiap individu

2. Bagaimana mengatasi kendala ketika persiapan presentasi seperti komputer belum siap dan tiba- tiba tidak berfungsi. Teap tenang adalah sikap yang akan menunjukkan branding kita terhadapa setiap orang.

3. Persiapan pembuatan merek dengan ssegala elemen yang sudah di persiapkan missal : namamerek, warna, tulisan dan bentuk packaging nantinya. Disini peserta dituntut mampu menjelaskan produk dan merek yang mereka miliki

4. Presentasi setiap kelompok untuk menjelaskan produk yang telah di beri label atau labeling, dengan kemmapuan presentasi dalam pembentukan personal branding, diharpapkan pesertamampu untuk memperesntasikan dan mempromosikan produk yang tekah dikemas dengan baik. 
DedikasiMU (Journal of Community Service)

Volume 3, Nomor 3, September 2021

Tabel 2. Tahapan Kegiatan

\begin{tabular}{|c|c|}
\hline TAHAPAN & KEGIATAN \\
\hline Sosialisasi & $\begin{array}{l}\text { Persamaan pemahaman anatar dosen dan seluruh } \\
\text { perangkat desa serta karang taruna } \\
\text { Jadwal pelaksanaan pelatihan yang disesuaikan } \\
\text { dengan jadwal Desa Klangonan. }\end{array}$ \\
\hline $\begin{array}{c}\text { Pelatihan Offline lokasi diSDN } \\
\text { Klangonan Giri }\end{array}$ & $\begin{array}{l}\text { 1) Menyiapkan Bahan Tayang } \\
\text { 2) Media pembelajaran } \\
\text { 3) Membawa produk } \\
\text { 4) Membawa contoh merek yang sudah ada atau } \\
\text { masih proses pembuatan }\end{array}$ \\
\hline Presentasi & $\begin{array}{l}\text { Peserta akan mempresentasikan hasil diskusi } \\
\text { kelompok di depan dosen dan seluruh peserta lainnya. }\end{array}$ \\
\hline
\end{tabular}
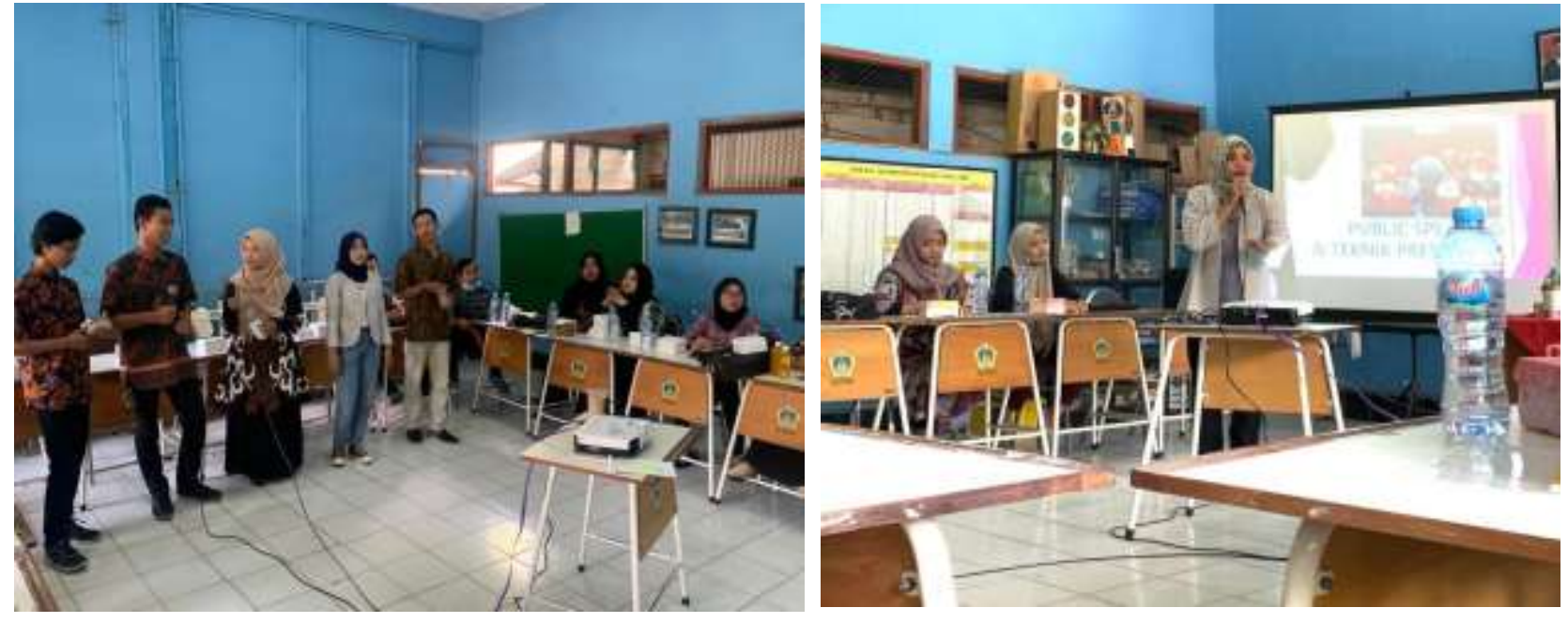

Gambar 1. Pelaksanaan Kegiatan Personal Branding 


\section{DedikasiMU (Journal of Community Service)}

Volume 3, Nomor 3, September 2021

\section{HASIL DAN PEMBAHASAN}

Berdasarkan hasil pelatihan dan pendampingan yang telah dilakukan di desa klangonan Giri yaitu Pelatihan dan Pengembangan Personal Branding serta Product Branding. Public Speaking dalam membentuk personal branding sangat penting untuk dipelajari oleh anggota karang Taruna, yang nantinya dapat diterapkan dalam melaksanakan tugas pokok sebagai pelaksana pada kegiatan desa, dan juga dapat menularkan ilmu Public Speaking ini kepada personel lainnya ketika bertugas di satuan kewilayahan. Penyelenggaraan pelatihan Personal Branding merupakan bentuk nyata komitmen peangkat desa dalam upayanya meningkatkan kemampuan para anggota karang taruna terkait dengan penciptaan berbagai langkah positif dan taktis dalam membanngun opini public yang menguntungkan bagi instansi serta melatih keterampilan personel agar mampu dan cakap membaca situasi, permasalahan yang muncul dalam masyarakat. Begitupula dengan pelatihan product branding yang dilakukan oleh anggota karang taruna adalah salah satu bentuk usaha para pelaku usaha kecil yang sebagian dari anggota karang taruna yakni untuk Memberikan daya tarik bagi konsumen atas produk yang sudah dimiliki, memudahkan perusahaan mendapatkan loyalitas pelanggan terhadap produk, membuka peluang usaha untuk menetapkan harga jual yang tinggi dan Peluang bagi pelaku usaha dalam melakukan diferensiasi produk.

Dalam kegiatan ini dapat diperoleh beberapa keluhan yang disampaikan oleh peserta

1. Karang taruna merasa kesulitan untuk melakukan personal branding karena masih mempunyai keraguan dan ketidakpercayaan diri ketika berbicara didepan umum. Belum bisa melakukan body laguange dengan percaya diri pula. Dan pada saat pelatihan telah di lakukan pelatihan terkait dengan pembentukan personal branding missal berbicara penuh percaya diri dengan baik Ketika didepan umum, memiliki kalimat- kalimat terstruktur Ketika melakukan presentasi di depan umum, memiliki sosial media dan dikelola dengan baik. 


\section{DedikasiMU (Journal of Community Service)}

Volume 3, Nomor 3, September 2021

2. Di desa Klangonan karang taruna harus berusaha keras untuk bisa menyampaikan atau mensosialisasikan ketika ada kegiatan desa kepada pemuda lainnya dan juga masyarakat. Karena tidak bisa dipungkiri Ketika mereka belajar public speaking dan bisa melakukan personal branding, maka kepercayaan masyarakat akan semakin tinggi dan mudah untuk mengajak masyarakat berpartisipasi dalam berkegiatan di desa. Pada saat pelatihan para peserta mulai mempraktikkan cara berbicara yang baik dan percaya diri dan saatnya nanti Ketika melakukan kegiatan di desa para peserta telah siap dan juga sudah lebih percaya diri

3. Lemahnya dalam membuat merek dan melakukan labeling terhadap produk usaha kecil. Pada saat pelatihan telah ada tugas untuk membuat product branding peserta telah melakukan praktik labeling misalnya pembentukan nama produk, warna, logo dan lainnya

4. Lemahnya media promosi untuk memasarkan produk usaha kecil yang sudah ada. Mulai disarankan menggunakan platform jual online missal di marketplace atau sosial media.

\section{KESIMPULAN DAN SASARAN}

\section{A. Kesimpulan}

1. Peningkatan kepercayaan diri oleh setiap peserta yaitu anggota karang taruna dalam menyampaikan pendapat dan juga materi ketika melaksanakan kegiatan sosialisasi.

2. Kesiapan diri dalam melakukan kegiatan sebagai anggota karang taruna telah dimiliki olehpeserta. Anggota karang taruna percaya bahawa tugas mereka adalah untuk bisa membantudesa dalam melakukan kegiatan dalam pengembangan desa.

3. Para anggota karang taruna telah memiliki kemampuan dalam hal pemasaran misalnya labeling dan membuat merek produk, logo, warna dan juga font.

4. Mulai mematangkan persiapan dalam membuat media promosi di berbagai platform, marketplace atau sosial media. Misalnya membuat iklan audio visual. 


\section{DedikasiMU (Journal of Community Service)}

Volume 3, Nomor 3, September 2021

\section{B. Saran}

1. Mengadakan pembaharuan pelatihan public speaking untuk membentuk personal branding anggota karang taruna per periode misal 6 bulan sekali untuk membiasakan danmelatih anggota karang taruna melatih kebiasaan diri. lalu berbicara umum, karena terkait tugas untuk membantu kegiatan desa. Lalu dilanjutkan Kembali pelatihan dengan para perangkat desa.

2. Melakukan evaluasi per periode pula terkait dengan pelatihan product branding terhadap produk usaha peserta dan masyarakat agar bisa melakukan perbaikan setiap waktu setiap kali dibutuhkan.

\section{DAFTAR PUSTAKA}

Haroen, Dewi. (2014). Personal Branding. Kunci Kesuksesan Anda Berkiprah Di dunia Politik. PT Gramedia Pustaka Utama.

Kotler, Philip. (2009). Manajemen Pemasaran. Edisi tiga belas Bahasa Indonesia. Jilid 1 dan 2. Jakarta : Erlangga.

Montoya, Peter. (2002). The Personal Branding Phenomenon. first edition published, Library of Congress. 